\title{
Pengaruh Substitusi Amtabis yang difermentasi dengan aspergillus niger terhadap Berat dan Persentase Karkas Broiler
}

\author{
(Effect of Substitution Amtabis Fermented with Aspergillus niger
}

on the Weight and the Percentage of Carcass Broiler)

\author{
Rifki Marzani ${ }^{1}$, Samadi ${ }^{1}$ dan Herawati ${ }^{1}$ \\ ${ }^{1}$ Program Studi Peternakan, Fakultas Pertanian, Universitas Syiah Kuala
}

\begin{abstract}
Abtrak- Tujuan penelitian ini adalah untuk mengetahui tentang pengaruh substitusi amtabis yang difermentasi dengan Aspergillus niger (A.niger) terhadap berat dan persentase karkas broiler. Penelitian ini dilakukan di Laboratorium Lapangan Peternakan Fakultas Pertanian Universitas Syiah Kuala yang berlokasi di Desa Kopelma Darussalam Banda Aceh sejak tanggal 4 Desember 2015 sampai dengan tanggal 9 Januari 2016. Parameter yang diukur adalah berat hidup, berat karkas, persentase karkas, berat potongan karkas, persentase potongan karkas. Hasil penelitian menunjukkan bahwa substitusi Amtabis dengan ransum komersial berpengaruh sangat nyata $(\mathrm{P}<0,01)$ terhadap berat hidup dan berat karkas, namun tidak berpengaruh nyata terhadap persentase karkas. Pada penambahan Amtabis dengan level 6\% cenderung menaikkan berat hidup, berat dan persentase karkas tetapi tidak melebihi kontrol. Pengaruh substitusi Amtabis terhadap berat dan persentase bagian-bagian karkas menunjukkan pengaruh yang nyata pada berat sayap, berat paha atas dan berat paha bawah.
\end{abstract}

Kata kunci : Ayam broiler, Amtabis, substitusi, karkas, pakan fermentasi.

Abstrack - The purpose of this study was to obtain information about the effect of substitution amtabis fermented with Aspergillus niger (A.niger) on broiler weight and the percentage of carcass. This research was conducted at the Field Laboratory of Animal Husbandry Department, Agricultural Faculty, Syiah Kuala Universtiy Darusslam, Banda Aceh from December 4, 2015 to January 9, 2016. Parameters measured in this study were live weight, carcass weight, carcass percentage, pieces of carcass weight, carcass percentage cuts. The results showed that the substitution of Amtabis in commercial rations significant effect $(\mathrm{P}<0,05)$ on live weight and carcass weight, but not influenced $(\mathrm{P}>0,05)$ on carcass percentage. Substitution of Amtabis at the level of $6 \%$ on commercial feed tended to increase live weight, carcass weight and percentages but still not above control weight. Effect of substitution Amtabis on weight and cut-up pieces of broiler carcass showed significantly influenced on the weight of the wings, tights and drum sticks.

Keywords: Broiler Chicken, Amtabis, substitution, commercial feed and carcass.

\section{PENDAHULUAN}

Pertambahan penduduk di Indonesia mengalami peningkatan dari tahun ke tahun. Hal yang sama juga terjadi pada permintaan daging ayam, dimana pada tahun 2010-2014 berturutturut adalah 1,540 1,665 1,734 1,895 1,938 ton per tahun (Dirjen Peternakan, 2014). Data tersebut menunjukkan adanya korelasi positif antara laju pertumbuhan penduduk Indonesia 
dengan tingkat kebutuhan daging ayam broiler. Usaha peternakan unggas diharapkan mampu memenuhi kebutuhan daging ayam sebagai sumber protein hewani. Murtidjo (2003), menyatakan bahwa daging broiler dipilih sebagai salah satu alternatif, karena diketahui bahwa broiler sangat efisien berproduksi dimana dalam waktu 4-5 minggu, ayam tersebut sanggup mencapai berat hidup $1,8-2 \mathrm{~kg}$.

Dalam suatu usaha peternakan, pakan memegang peranan yang sangat penting baik ditinjau dari segi produksi maupun dari segi ekonomi. Sementara dari segi ekonomi, lebih kurang $70 \%$ biaya produksi dihabiskan untuk memenuhi kebutuhan pakan ternak (Widodo, 2008). Oleh karena itu, perlu dicari solusi untuk mendapatkan bahan pakan ternak yang berkualitas dengan harga bersaing.

Salah satu limbah industri pertanian yang dapat dijadikan sebagai pakan alternatif adalah bungkil inti sawit (BIS) dan ampas tahu. Namun BIS mengandung serat kasar yang tinggi, mencapai $21,08 \%$ dan protein yang rendah yaitu $15,4 \%$ (Nuraini, 2002). Untuk mencukupi kandungan protein yang rendah maka ditambahkan ampas tahu yang ketersediannya pada saat ini sangat banyak dan harganya yang relatif murah (Muis et al., 2010). Sementara untuk menurunkan kadar serat kasar yang tinggi dilakukan proses fermentasi menggunakan jamur Aspergillus niger (A.niger).Pakan hasil limbah yang digunakan pada penelitian ini adalah Amtabis. Amtabis adalah pakan fermentasi ampas tahu dan BIS dengan menggunakan mikroba dari jenis jamur A.niger (Nurliana et al., 2015). Pembuatan Amtabis ini menggunakan metode fermentasi yang dipakai oleh (Supriyadi, 1995) yang kemudian dimodifikasi oleh Nurliana et al. (2015) dengan penambahan sterilisasi basah.

\section{Tempat dan Waktu Penelitian}

\section{MATERI DAN METODE}

Penelitian ini dilaksanakan di Laboratorium Lapangan Peternakan Universitas Syiah Kuala yang berlokasi di Desa Kopelma Darussalam Banda Aceh sejak tanggal 4 Desember 2015 sampai dengan tanggal 9 Januari 2016.

\section{Materi Penelitian}

Materi yang digunakan dalam penelitian ini adalah 100 ekor day old chick (DOC) ayam broiler, strain CP 707, produksi PT. Charoen Pokphand Jaya Farm, Medan.

\section{Alat dan Bahan Penelitian}

Alat-alat yang digunakan dalam penelitian ini adalah kandang bersekat 100x100 cm, tempat pemberian ransum, tempat pemberian air minum, timbangan digital, terpal tempat mengaduk ransum, lampu pijar, kapur, label kandang, ember, thermometer, buku catatan, alat tulis, lampu minyak, sprayer, kipas angin, dan peralatan penunjang kandang. Bahan yang digunakan dalam penelitian adalah ransum komersial broiler (511 Bravo produksi PT. Charoen Pokphand), Amtabis (ampas tahu dan bungkil inti sawit), Vitastress, Vaksin Gumboro, Vaksin ND, A. niger, litter dan air.

\section{Rancangan Penelitian}

Penelitian ini merupakan penelitian eksperimental yang menggunakan Rancangan Acak Lengkap (RAL). 


\section{HASIL DAN PEMBAHASAN}

\section{Pengaruh Perlakuan Terhadap Berat Hidup, Berat Karkas dan Persentase Karkas Berat Hidup}

Berat hidup merupakan berat dari hasil penimbangan ayam setelah dipuasakan selama \pm 12 jam. Pengaruh pemberian substitusi Amtabis dalam ransum komersial dalam berbagai taraf terhadap berat hidup ayam broiler pada umur 35 hari pada masing-masing perlakuan ditampilkan pada pada Tabel 1.

Tabel 1. Rataan Berat Hidup Ayam Broiler yang diberi Ransum Komersial dengan Substitusi Amtabis

\begin{tabular}{cc}
\hline Perlakuan & Rataan Berat Hidup \\
\hline P0 & $2216,0^{\mathrm{a}} \pm 48,821$ \\
P1 & $1952,8^{\mathrm{b}} \pm 49,009$ \\
P2 & $1994,4^{\mathrm{b}} \pm 37,505$ \\
P3 & $2014,4^{\mathrm{b}} \pm 31,733$ \\
\hline
\end{tabular}

Keterangan : a,b,c pada baris sama dengan supskrip berbeda menyebabkan perbedaan yang sangat nyata $(\mathrm{P}<0,01)$

Hasil sidik ragam menunjukkan bahwa pemberian berbagai jenis ransum perlakuan berpengaruh sangat nyata $(\mathrm{P}<0,01)$ terhadap berat hidup ayam broiler. Dimana penambahan Amtabis pada pemakaian 2\% mengalami penurunan berat badan, pada pemakaian $4 \%$ dan $6 \%$ mengalami kenaikan meskipun tidak setinggi pada perlakuan kontrol. Hasil uji Duncan memperlihatkan bahwa penggunaan Amtabis 0\% (P0) berbeda sangat nyata dengan $\mathrm{P} 1, \mathrm{P} 2$, dan P3. Penggunaan Amtabis pada taraf 6\% menunjukkan peningkatan lebih baik terhadap berat hidup ayam broiler, karena pada pemakaian Amtabis $6 \%$ berat hidup ayam kembali mengalami peningkatan.

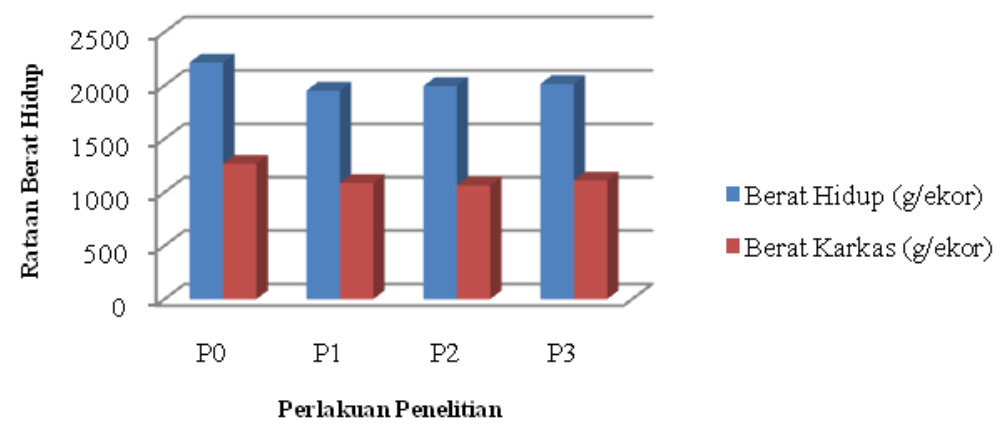

Grafik 1. Rataan Berat Hidup dan Berat Karkas Ayam Broiler Selama Penelitian Selama 35 Hari Penelitian.

Rataan berat hidup ayam broiler selama penelitian sekitar 1952,8-2216 gram dengan menggunakan strain CP 707, hasil ini lebih tinggi dibandingkan yang dikemukakan Vantress (2008) bahwa berat hidup broiler strain cob adalah sebesar 1397 gram. Wahyu (2004) menyebutkan bahwa faktor-faktor yang mempengaruhi berat hidup ayam broiler yaitu konsumsi ransum, kualitas ransum, jenis kelamin, lama pemeliharaan dan aktivitas.

\section{Berat Karkas}

Berat karkas adalah berat yang diperoleh dari hasil penimbangan ayam tanpa bulu, leher, kepala, kaki, jeroan dan darah. Rataan berat karkas ayam broiler dari hasil penelitian pada masing-masing perlakuan dapat dilihat pada Tabel 2. 
Tabel 2. Rataan Berat Karkas Ayam Broiler yang diberi Ransum Komersial dengan Substitusi Amtabis

\begin{tabular}{cc}
\hline Perlakuan & Rataan Berat Karkas \\
\hline P0 & $1268,0^{\mathrm{a}} \pm 50,09$ \\
P1 & $1088,2^{\mathrm{b}} \pm 32,88$ \\
P2 & $1063,6^{\mathrm{b}} \pm 27,95$ \\
P3 & $1110,0^{\mathrm{b}} \pm 32,81$ \\
\hline
\end{tabular}

Keterangan : a,b,c pada baris sama dengan supskrip berbeda menyebabkan perbedaan yang sangat nyata $(\mathrm{P}<0,01)$

Hasil sidik ragam menunjukkan bahwa pemberian berbagai jenis ransum perlakuan berpengaruh sangat nyata $(\mathrm{P}<0,01)$ terhadap berat karkas ayam broiler. Hal ini dikarenakan peningkatan berat hidup ayam broiler juga memberikan pengaruh yang sangat nyata. Hal ini sesuai dengan pendapat Soeparno (1998) bahwa tinggi rendahnya berat karkas sangat dipengaruhi berat badan ternak, semakin tinggi berat badan ternak maka berat karkas makin tinggi. Haroen (2003) juga mengungkapkan bahwa, pencapaian berat karkas sangat berkaitan dengan berat potong dan pertambahan berat badan.

Perlakuan kontrol menghasilkan berat karkas tertinggi diduga karena ransum P0 mempunyai kandungan energi dan protein yang lebih tinggi dibandingkan dengan perlakuan yang lain. Scott et al. (1982) menyatakan bahwa untuk mendapatkan berat karkas yang tinggi dapat dilakukan dengan memberikan ransum dengan imbangan yang baik antara protein, vitamin, mineral dan energi yang tinggi. Selanjutnya pendapat

Hasil penelitian menunjukkan bahwa berat karkas yang diperoleh berbanding lurus dengan berat hidup, dimana berat hidup yang tinggi juga diperoleh berat karkas yang tinggi, begitu pula sebaliknya. Hal ini sesuai dengan pendapat Kamal (1994) yang menyatakan bahwa apabila berat karkas yang didapatkan tidak berbeda nyata itu disebabkan karena berat potong yang didapatkan juga tidak berbeda nyata.

\section{Persentase Karkas}

Persentase karkas adalah hasil dari berat karkas dibagi dengan berat hidup dikali 100\%. Rataan berat karkas ayam broiler dari hasil penelitian dapat dilihat pada Tabel 3.

Tabel 3. Rataan Persentase Karkas Ayam Broiler yang diberi Ransum Komersial dengan Substitusi Amtabis

\begin{tabular}{cc}
\hline Perlakuan & Rataan Persentase Karkas \\
\hline P0 & $57,237 \pm 1,56$ \\
P1 & $55,70 \pm 0,56$ \\
P2 & $53,34 \pm 1,15$ \\
P3 & $55,05 \pm 0,89$ \\
\hline
\end{tabular}

Ket $: \mathrm{P} 0=100 \%$ pakan komersial $+0 \%$ Amtabis,

$\mathrm{P} 1=98 \%$ pakan komersial $+2 \%$ Amtabis,

$\mathrm{P} 2=96 \%$ pakan komersial $+4 \%$ Amtabis,

$\mathrm{P} 3=94 \%$ pakan komersial $+6 \%$ Amtabis.

Hasil sidik ragam menunjukkan bahwa pemberian berbagai jenis ransum perlakuan tidak berpengaruh nyata $(\mathrm{P}>0,05)$ terhadap persentase karkas ayam broiler. Persentase karkas yang dihasilkan dalam penelitian ini belum cukup baik, dimana persentase karkas yang dihasilkan berkisar antara 53-57\%. Menurut pendapat Mahfudz et al. (2004), yang menyebutkan bahwa persentase karkas ayam broiler adalah berkisar antara $62-66 \%$. Rataan 
persentase karkas ayam broiler dari hasil penelitian pada masing-masing perlakuan dapat dilihat pada Grafik 2.

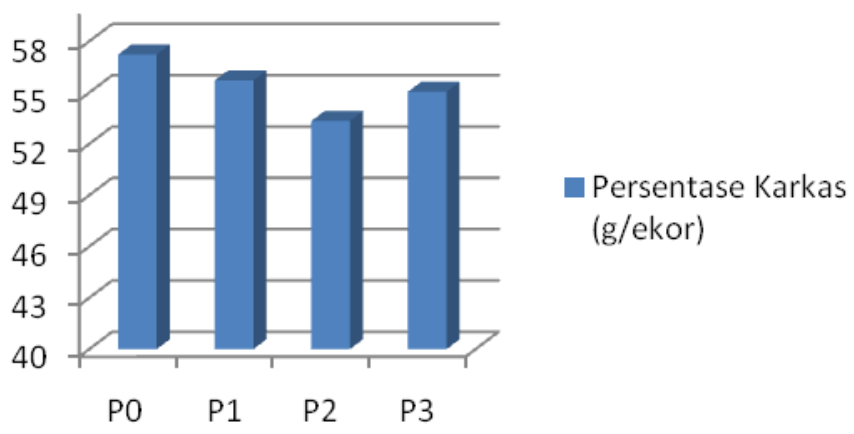

Grafik 2. Persentase Karkas Ayam Broiler Selama 35 Hari Pemeliharaan

Perlakuan kontrol menghasilkan berat karkas tertinggi diduga karena ransum P0 mempunyai kandungan energi dan protein yang lebih tinggi dibandingkan dengan perlakuan yang lain. Walaupun persentase tertinggi terdapat pada P0 namun secara statistik tidak menunjukkan perbedaan yang nyata. Persentase karkas merupakan perbandingan antara berat karkas dengan berat hidup yang sering digunakan sebagai pendugaan jumlah daging pada unggas (Abubakar dan Nataamijaya, 1999). Hal ini juga dikemukakan oleh Jull (1972) bahwa persentase karkas ditentukan oleh besarnya bagian tubuh yang terbuang, seperti kepala, leher, jeroan, bulu, dan darah.

\section{Pengaruh Perlakuan Terhadap Berat Bagian-Bagian Karkas dan Persentase Bagian- Bagian Karkas}

Tabel 11. Rataan Berat Potongan Karkas dan Persentae Potongan Karkas Ayam Broiler yang diberi Ransum Komersial dan Substitusi Amtabis

\begin{tabular}{|c|c|c|c|c|c|c|c|c|}
\hline \multirow{3}{*}{$\begin{array}{c}\text { Potongan } \\
\text { Bagian } \\
\text { karkas }\end{array}$} & \multicolumn{8}{|c|}{ Perlakuan } \\
\hline & \multicolumn{2}{|c|}{ P0 } & \multicolumn{2}{|c|}{ P1 } & \multicolumn{2}{|c|}{$\mathbf{P 2}$} & \multicolumn{2}{|c|}{ P3 } \\
\hline & Berat (g) & $\begin{array}{c}\text { Persentase } \\
(\%)\end{array}$ & Berat (g) & $\begin{array}{c}\text { Persentase } \\
(\%)\end{array}$ & Berat (g) & $\begin{array}{c}\text { Persentase } \\
(\%)\end{array}$ & Berat (g) & $\begin{array}{c}\text { Persentase } \\
(\%)\end{array}$ \\
\hline Dada & $\begin{array}{c}571,6 \pm \\
21,95\end{array}$ & $45,10 \pm 0,66$ & $\begin{array}{c}509,2 \pm \\
22,89\end{array}$ & $\begin{array}{c}46,73 \pm \\
0,89\end{array}$ & $\begin{array}{c}502,8 \pm \\
17,79\end{array}$ & $\begin{array}{c}47,24 \pm \\
0,66\end{array}$ & $508 \pm 18,77$ & $45,77 \pm 1,08$ \\
\hline Sayap & $\begin{array}{c}122,6 \pm \\
4,34^{\mathrm{a}}\end{array}$ & $9,70 \pm 0,38$ & $\begin{array}{c}109,4 \pm \\
3,68^{\mathrm{ab}}\end{array}$ & $\begin{array}{c}10,07 \pm \\
0,37\end{array}$ & $\begin{array}{l}98,6 \pm \\
4,02^{b}\end{array}$ & $9,28 \pm 0,37$ & $\begin{array}{c}113,2 \pm \\
5,60^{\mathrm{a}}\end{array}$ & $\begin{array}{c}10,18 \pm \\
0,26\end{array}$ \\
\hline Paha Atas & $\begin{array}{l}244,6 \pm \\
24,34^{\mathrm{a}}\end{array}$ & $19,13 \pm 1,24$ & $\begin{array}{c}200,8 \pm \\
6,69^{\mathrm{ab}}\end{array}$ & $\begin{array}{c}18,04 \pm \\
0,85\end{array}$ & $\begin{array}{c}181,6 \pm \\
8,26^{\mathrm{b}}\end{array}$ & $\begin{array}{c}17,11 \pm \\
0,87\end{array}$ & $\begin{array}{l}184,2 \pm \\
14,18^{b}\end{array}$ & $\begin{array}{c}16,57 \pm \\
1,05\end{array}$ \\
\hline $\begin{array}{l}\text { Paha } \\
\text { Bawah }\end{array}$ & $\begin{array}{c}215,8 \pm \\
5,88^{\mathrm{a}}\end{array}$ & $17,09 \pm 0,65$ & $\begin{array}{c}169,4 \pm \\
6,42^{b}\end{array}$ & $\begin{array}{c}15,57 \pm \\
0,47\end{array}$ & $182 \pm 8,99^{b}$ & $\begin{array}{c}17,10 \pm \\
0,64\end{array}$ & $\begin{array}{c}177,8 \pm \\
4,87^{\mathrm{b}}\end{array}$ & $16,03 \pm 0,25$ \\
\hline Punggung & $113,4 \pm 6,59$ & $8,96 \pm 0,45$ & $98,8 \pm 7,72$ & $9,04 \pm 0,49$ & $99,2 \pm 6,80$ & $9,31 \pm 0,57$ & $115,6 \pm 6,89$ & $\begin{array}{c}10,45 \pm \\
0,73\end{array}$ \\
\hline
\end{tabular}

Superscript yang berbeda pada baris yang sama menunjukkan perbedaan yang sangat nyata $(\mathrm{P}<0,01) . \mathrm{P} 0$ $=100 \%$ pakan komersial $+0 \%$ Amtabis, $\mathrm{P} 1=98 \%$ pakan komersial $+2 \%$ Amtabis, $\mathrm{P} 2=96 \%$ pakan komersial $+4 \%$ Amtabis, P3 $=94 \%$ pakan komersial $+6 \%$ Amtabis.

\section{Berat dan Persentase Dada}

Rataan berat dan persentase dada ayam broiler dari hasil penelitian pada masingmasing perlakuan dapat dilihat pada Tabel 4. Hasil sidik ragam menunjukkan bahwa pemberian ransum komersial dengan substitusi Amtabis tidak berpengaruh nyata $(\mathrm{P}>0,05)$ 
terhadap berat dan persentase dada. Hal ini sesuai dengan pendapat Soeparno (1998) bahwa ada hubungan yang erat antara berat karkas dan bagian-bagian karkas dengan berat potong, sehingga apabila dari hasil analisis berat potong dan karkas didapat hasil yang tidak berpengaruh nyata maka hasilnya tidak jauh berbeda pada bagian karkasnya, sebaliknya apabila dari hasil analisis berat potong dan berat karkas didapat hasil yang berbeda nyata maka hasilnya tidak jauh berbeda pada bagian karkasnya.

Namun secara statistik tidak menunjukkan perbedaan yang nyata. Hasil rata - rata persentase daging dada dalam penelitian ini lebih tinggi dibandingkan dengan penelitian Resnawati (2004) yang melaporkan bahwa persentase dada ayam pedaging berkisar 24,13 $26,79 \%$. Tingginya persentase berat daging dada diduga disebabkan oleh berat karkas yang tinggi pada umur pemeliharaan 35 hari.

\section{Berat dan Persentase Sayap}

Rataan berat sayap ayam broiler dari hasil penelitian pada masing-masing perlakuan dapat dilihat pada Tabel 4. Hasil sidik ragam menunjukkan bahwa pemberian ransum komersial dengan substitusi Amtabis berpengaruh nyata $(\mathrm{P}<0,05)$ terhadap berat potongan karkas sayap. Hasil uji Duncan menunjukkan bahwa $\mathrm{P} 0$ berbeda nyata $(\mathrm{P}<0,05)$ dengan $\mathrm{P} 2$ dan $\mathrm{P} 3$ berbeda nyata $(\mathrm{P}<0,05)$ dengan $\mathrm{P} 2$.

Rataan persentase sayap ayam broiler dari hasil penelitian pada masing-masing perlakuan dapat dilihat pada (Tabel 4). Hasil sidik ragam menunjukkan bahwa pemberian ransum komersial dengan substitusi Amtabis tidak berpengaruh nyata $(\mathrm{P}>0,05)$ terhadap persentase sayap. Hasil penelitian menunjukkan bahwa pada perlakuan (P3) ada kecenderungan lebih tinggi terhadap persentase sayap dari semua perlakuan, namun secara statistik tidak menunjukkan perbedaan yang signifikan antar perlakuan. Hal ini sesuai dengan pendapat Achmanu et al. (1997) bahwa berat karkas akan mempengaruhi persentase karkas dan bagian-bagiannya. Bagian dada dan paha berkembang lebih dominan selama pertumbuhan dibandingkan pada bagian sayap (Abu Bakar dan Nataamijaya,1999). Persentase karkas sayap tertinggi diperoleh pada perlakuan P3 (10,18\%), selanjutnya P1 yaitu $(10,07 \%)$ dan P0 $(9,71 \%)$ dan terendah pada perlakuan P2(9,28\%).

\section{Berat dan Persentase Paha Atas}

Rataan berat dan persentase paha atas ayam broiler dari hasil penelitian pada masingmasing perlakuan dapat dilihat pada Tabel 4 . Hasil sidik ragam menunjukkan bahwa pemberian ransum komersial dengan substitusi Amtabis berpengaruh nyata $(\mathrm{P}<0,05)$ terhadap berat karkas paha atas, namun untuk persentase paha atas tidak berpengaruh nyata $(\mathrm{P}>0,05)$. Semakin tinggi berat karkas maka semakin tinggi pula persentase bagian karkas. Berat karkas paha atas tertinggi diperoleh pada perlakuan P0 (244,6 gram), selanjutnya P1 (200,8 gram) dan P3 (184,2 gram) dan terendah pada perlakuan P2 (181,6 gram).

\section{Berat dan Persentase Paha Bawah}

Rataan berat dan persentase paha bawah ayam broiler dari hasil penelitian pada masing-masing perlakuan dapat dilihat pada Tabel 4. Hasil sidik ragam menunjukkan bahwa pemberian ransum komersial dengan substitusi Amtabis berpengaruh sangat nyata $(\mathrm{P}<0,01)$ terhadap berat karkas paha bawah, namun untuk persentase paha bawah tidak berpengaruh nyata $(\mathrm{P}>0,05)$. 
Berat karkas paha bawah tertinggi diperoleh pada perlakuan P0 (215,8 gram), selanjutnya P2 (182 gram) dan P3 (177,8 gram) dan terendah pada perlakuan P2 (182 gram). Hasil uji Duncan menunjukkan bahwa pemberian Amtabis 0\% (P0) berbeda sangat nyata $(\mathrm{P}<0,01)$ dengan $\mathrm{P} 1, \mathrm{P} 2$, dan $\mathrm{P} 3$. Persentase paha bawah tertinggi diperoleh pada perlakuan P2 $(17,10 \%)$, selanjutnya P0 $(17,09 \%)$ dan P1 $(16,03 \%)$ dan terendah pada perlakuan P3 $(15,57 \%)$.

Bagian paha dipisahkan pada aceta bulum, yang terdiri dari otot besar dan pada umumnya menghasilkan daging dengan keempukan sedang sampai empuk, dan memiliki harga yang cukup mahal (Soeparno, 1992).

\section{Berat dan Persentase Punggung}

Rataan berat punggung ayam broiler dari hasil penelitian pada masing-masing perlakuan dapat dilihat pada Tabel 4. Hasil sidik ragam menunjukkan bahwa pemberian ransum komersial dengan substitusi Amtabis tidak berpengaruh nyata $(\mathrm{P}>0,05)$ terhadap berat dan persentase punggung. Hal ini diduga karena bagian punggung broiler merupakan bagian yang lebih banyak tulang dibandingkan bagian yang lain. Perlakuan pemberian pakan ternyata tidak mempengaruh berat dan persentase punggung.

Berat karkas punggung tertinggi diperoleh pada perlakuan P3 (115,6 gram), selanjutnya P0 (113,4 gram) dan P2 (99,2 gram) dan terendah pada perlakuan P1 (98,8 gram).

Persentase bagian karkas punggung tertinggi diperoleh pada perlakuan P3 (10,45\%), selanjutnya P2 $(9,31 \%)$ dan P1 $(9,04 \%)$ dan terendah pada perlakuan P0(8,96\%). Namun secara statistik tidak menunjukkan perbedaan yang nyata.

Suswoyo et al. (1992) menyatakan bahwa punggung didominasi oleh daging yang langsung menempel pada Columna vertebralis sternum dan tulang yang lain.

\section{KESIMPULAN}

Dari hasil penelitian yang telah dilakukan dapat disimpulkan bahwa substitusi amtabis dalam ransum komersial berpengaruh sangat nyata $(\mathrm{P}<0,01)$ terhadap berat hidup dan berat karkas, namun tidak berpengaruh nyata $(\mathrm{P}>0,05)$ terhadap persentase karkas. Substitusi amtabis pada level 6\% cenderung menaikkan berat hidup, berat dan persentase karkas tetapi tidak melebihi kontrol. Substitusi amtabis pada pakan komersil berpengaruh nyata $(\mathrm{P}<0,05)$ terhadap berat dan persentase bagian-bagian karkas terutama pada berat sayap, berat paha atas dan berat paha bawah.

\section{DAFTAR PUSTAKA}

Abubakar dan A.G. Nataamijaya. 1999. Persentase Karkas dan Bagianbagiannya Dua Galur Ayam Broiler dengan Penambahan Tepung Kunyit (Curcuma domestica Val) dalam Ransum. Buletin Peternakan. Edisi Khusus. Fakultas Peternakan. Universitas Gadjah Mada, Yogyakarta.

Achmanu., Rahardjo dan Koentjoko, 1997. Pengaruh Tingkat Penggunaan Tepung Sagu dalam Pakan Terhadap Penamilan Itik Mojosari Jantan. Agrivista. Fakultas Peternakan Universitas Brawijaya. Malang 20 (2) : 109 - 113

Direktorat Jenderal Peternakan. 2014. Produksi daging sapi dan daging ayam. Direktorat Jenderal Peternakan, Jakarta. 
Haroen, U. 2003. Respon Ayam Broiler yang Diberi Tepung Daun Sengon (Albizzia Falcataria) Dalam Ransum Terhadap Pertumbuhan Dan Hasil Karkas. J. Ilmiah Ilmu-Ilmu Peternakan. 6 (1) : 34-41.

Jull, M.A. 1972. Poultry Husbandry. Ed ke-3. New York: Tatu McGraw Hill.

Kamal, M. 1994. Nutrisi Ternak I. Fakultas Peternakan. Universitas Gadjah Mada, Yogyakarta.

Mahfudz, L.D., W. Sarengat, D.S. Prayitno, dan U. Atmomarsono. 2004. Ampas Tahu yang Difermentasi dengan Laru Oncom sebagai Pakan Ayam Ras Pedaging. Laboratorium Ilmu Ternak Unggas, Fakultas Peternakan,Universitas Diponegoro, Semarang

Muis, H., I. Martaguri dan Mirnawati. 2010. Teknologi Bioproses Ampas kedele (Soybean waste) untuk Meningkatkan Daya Gunanya sebagai Pakan Unggas. Laporan Penelitian Fundamental. Universitas andalas

Murtidjo, M.A.B. 2003. Pedoman Meramu pakan Unggas. Kanisius, Yogyakarta.

Nuraini. 2002. Pengaruh penggunaan bungkil inti sawit dalam ransum ayam broiler. Laporan Penelitian. Fakultas Perternakan Unand, Padang.

Nurliana, S. Wajizah dan D. Masyitha. 2015. Laporan Kemajuan Penelitian Hibah Bersaing, Universitas Syiah Kuala, Banda Aceh.

Resnawati H. 2004. Bobot potongan karkas dan lemak abdomen ayam ras pedaging yang diberi ransum mengandung tepung cacing tanah (Lumbricus rubellus). Di dalam: Prosiding Seminar Nasional Teknologi Peternakan dan Veteriner; Bogor, 17-18 Sep 2004. Bogor: Pusat Penelitian dan Pengembangan Peternakan. 2004. hlm 563567.

Scott, M.L., M.C. Nesheim Dan R.J. Young, 1982. Nutrition Of The Chicken. $3^{\text {rd }}$ Ed. M.L. Scott \& Association, Ithaca, New York.

Soeparno. 1998. Ilmu Dan Teknologi Daging. Yogjakarta (Indonesia) Gadjah Mada University Press.

Supriyadi. 1995. Pengaruh tingkat penggunaan hasil fermentasi kulit ubi kayu oleh jamur Aspergillus niger dalam ransum terhadap performa ayam pedaging periode starter [skripsi]. [Bandung (Indonesia)]: Universitas Padjajaran.

Suswoyo, I., Rosidi dan E. Tugiyanti. 1992. Bagian-Bagian Karkas Ayam Broiler Dibawah Pe0ngaruh Lantai Kandang Dan Frekuensi Pemberian Pakan Yang Berbeda. Laporan Hasil Penelitian. Fakultas Peternakan Unsoed, Purwokerto

Vantress. 2008. Broiler Peformance and Nutrition Supplement Cobb 500. Cobb Vantress Inc, Arkansas.

Wahyu, J. 2004. Ilmu Ternak Unggas. Cetakan Kelima. Gadjah Mada University Press, Yogyakarta.

Widodo, W. 2008. Ketahanan Pakan Unggas di Tengah Krisis Pangan. Fakultas Peternakan- Perikanan Universitas Muhammadiyah, Malang. 